\title{
INTEGRATED LEARNING IN DRAMA COURSE USING YOUTUBE
}

\author{
Ch. Evy Tri Widyahening, Ulupi Sitoresmi \\ Slamet Riyadi University, Surakarta-Indonesia \\ widyaheningchristiana@gmail.com
}

\begin{tabular}{l}
\hline Info Artikel \\
Masuk: 12 November 2020 \\
Revisi: 25 November 2020 \\
Diterima: 8 Desember 2020 \\
Terbit: 12 Januari 2021 \\
Keywords: \\
Service Quality, Poor \\
Family, and Health \\
\\
Pata kunci: \\
Kualitas Pelayanan, \\
Keluarga Miskin, dan \\
Kesehatan \\
D-ISSN: 2580-5819 \\
: 10.33061 \\
\end{tabular}

\begin{abstract}
This research is about the right of access to health services for people who participate in KIS in The Boyolali District. Problems arise when public policies from the central government are not in line with emerging policies. Various mistakes occur in these policies which will lead to the quality of public services in the health sector.

The research objective is to improve the quality of health services for the poor in Boyolali

The research method is a qualitative descriptive perspective with observational study techniques, in-depth interviews, and written document archives. Data processing and data analysis consist of data reduction, research data presentation, and levers.

Health Services at the Mojosong Public health center have exceeded the health service standards of Permenkes Number 43 of 2016, however, there is one item of maternal care because there is no inpatient room so that the puskesmas will measure it to a hospital that has these facilities. , the services provided by the Public health center are felt to be more than good enough about medical administration services.

\begin{tabular}{l} 
Abstrak \\
\hline Penelitian ini membahas tentang hak akses pelayanan kesehatan bagi \\
masyarakat peserta KIS di Kabupaten Boyolali. Masalah muncul ketika \\
kebijakan publik dari pemerintah pusat tidak sejalan dengan kebijakan \\
yang sedang berkembang. Berbagai kesalahan terjadi dalam kebijakan \\
tersebut yang akan berdampak pada kualitas pelayanan publik di bidang \\
kesehatan. \\
Tujuan penelitian adalah untuk meningkatkan kualitas pelayanan \\
kesehatan bagi masyarakat miskin di Boyolali \\
Metode penelitian yang digunakan adalah deskriptif kualitatif dengan \\
teknik studi observasional, wawancara mendalam, dan arsip dokumen \\
tertulis. Pengolahan data dan analisis data terdiri dari reduksi data, \\
penyajian data penelitian, dan pengungkit. \\
Pelayanan Kesehatan di Puskesmas Mojosong telah melebihi standar \\
pelayanan kesehatan pada Permenkes Nomor 43 Tahun 2016, namun \\
demikian terdapat salah satu item perawatan ibu karena tidak ada ruang \\
rawat inap sehingga puskesmas akan melakukan pengukuran ke rumah \\
sakit yang memiliki fasilitas tersebut. ., pelayanan yang diberikan oleh \\
Puskesmas dirasa lebih dari cukup baik tentang pelayanan administrasi \\
medik.
\end{tabular}
\end{abstract}

\section{PENDAHULUAN}

\section{LATAR BELAKANG}

Kesehatan merupakan salah satu hak setiap warga Negara sehingga bersifat esensial dan harus dipenuhi sehingga harus dilindungi oleh konstitusi. Perlindungan hak warga negara Indonesia khususnya kesehatan diatur dalam UU RI No. 36 Tahun 2009 tentang kesehatan pasal 5 ayat (1) yang berbunyi "setiap orang mempunyai hak yang sama dalam memperoleh akses atas sumber daya di bidang kesehatan". Masyarakat Indonesia kenyataanya masih sulit menjangkau layanan kesehatan yang memadai. Beberapa factor penyebabnya seperti mahalnya biaya akses layanan kesehatan serta kondisi masyarakat Indonesia yang terbelenggu kemiskinan. Berdasarkan hal itu kabupaten Boyolali mempunyai 
visi :"proinvestasi mewujudkan Boyolali yang maju dan lebih sejahter". Visi tersebut ingin mewujudkan kondisi masyarakat yang semakin sejahtera, serta kondisi yang semakin kondusif dan modern dengan tetap memperhatikan lingkungan berkelanjutan demi kemajuan perindustrian, perdagangan dan jasa, dan hal ini tidak lepas dari masyarakat yang sehat.Dengan dasar ini, setiap individu, keluarga dan masyarakat melalui program kesehatan difasilitasi agar mampu mengambil keputusan yang tepat ketika membutuhkan pelayanan kesehatan. fasilitas pelayanan kesehatan yang ada perlu terus diberdayakan agar mampu memberikan pertolongan kesehatan yang berkualitas, terjangkau, sesuai dengan norma sosial budaya setempat serta tepat waktu, adil dan merata . Kesempatan untuk memperoleh pelayanan kesehatan yang berkualitas, terjangkau dan tepat waktu, tanpa memandang perbedaan ras, golongan, agama, dan status sosial individu, keluarga dan masyarakat. Pembangunan kesehatan harus terus diimbangi dengan upaya-upaya kesehatan yang bersifat rujukan, bersifat luar gedung maupun yang bersifat satelit pelayanan. Dengan demikian pembangunan kesehatan dapat menjangkau kantongkantong penduduk beresiko tinggi yang merupakan penyumbang terbesar kejadian sakit dan kematian. Kelompok-kelompok penduduk inilah yang sesungguhnya lebih membutuhkan pertolongan karena selain lebih rentan terhadap penyakit, kemampuan membayar mereka jauh lebih sedikit. Program kesehatan diselenggarakan agar memberikan manfaat yang sebesarbesarnya bagi peningkatan derajat kesehatan masyarakat. Program kesehatan diselenggarakan dengan penuh tanggung jawab, sesuai dengan standar profesi dan peraturan perundang-undangan yang berlaku serta mempertimbangkan dengan sungguh-sungguh kebutuhan dan kondisi spesifik daerah.

Berdasarkan hasil survei yang dilakukan oleh Badan Pusat Statistik penduduk miskin Kabupaten Boyolali dapat digambarkan seperti tabel di bawah ini.

\begin{tabular}{|l|l|l|}
\hline Th 2016 & 117.000 & $12.07 \%$ \\
\hline Th 2017 & 116.400 & $11.96 \%$ \\
\hline Th 2018 & 98.230 & $10.04 \%$ \\
\hline Th 2019 & 93.750 & $9,53 \%$ \\
\hline
\end{tabular}

Kondisi kemiskinan ini berdampak kepada aspek lain dalam kehidupan seperti tingkat kesehatan. Hardiyansyah dalam bukunya yang berjudul "Kualitas Pelayanan Publik, Konsep, Dimensi, Indikator dan 3 Implementasinya" (2011:20) menyebutkan bahwa keterkaitan antara tingkat kesehatan dengan kemiskinan sebagai "the vicious circle of poverty. Tindak lanjut implementasi kebijakan pembangunan kesehatan sejak 1 Maret 2015 pemerintah mengeluarkan KIS yang dikelola BPJS. KIS terdiri dari asuransi kesehatan yang bisa dibayar secara mandiri, perusahan dan khusus masyarakat miskin yang terdaftar dalam BDT dibayar pemerintah. Pemerintah kabupaten boyolali mempunyai 3 pokok prioritas yaitu program STBM (Sanitasi Total Berbasis Masyarakat) penurunan angka kematian ibu dan anak dan program jaminan kesehatan. Ketiga prioritas tersebut diutamakan karena dinkes Boyolali melayani dari kandungan sampai lansia. Tujuan program adalah agar kesehatan, khususnya kabupaten Boyolali mampu tumbuh dan meningkat untuk mewujudkan satu komitmen bersama melalui gerakan masyarakat hidup sehat. Mendindaklanjuti instruksi Presiden Indonesia Nomor 8 Tahun 2017 tentang Optimaliasi Pelaksanaan JKN, Pemerintah Kabupaten (Pemkab) Boyolali menerbitkan Instruksi Bupati Nomor 1158 Tahun 2018 Tentang Optimalisasi Pelaksanaan Program JKN Boyolali. Wujud nyata instruksi tersebut yakni penambahan kuota kepesertaan PBI oleh Pemkab Boyolali yang semula 12.308 menjadi 25.308. Dalam rangka melaksanakan instruksi tersebut, berbagai kegiatan yang sudah dilaksanakan salah satunya pemadanan data antara data Dinas Kependudukan, data BDT dan data BPJS Kesehatan, Pemadanan data badan usaha/perusahaan dengan BPJS Kesehatan serta Penegakan kepatuhan pemberi kerja. 
Terkait dengan kebijakan pelayanan kesehatan nasional, terjadi masa transisi dari sistem pelayanan BPJS menjadi KIS melalui program JKN yang menimbulkan masalah. Permasalahan teknis terkait petugas pelayanan kesehatan di tingkat bawah antara lain keterbatasan sosialisasi dan petunjuk teknis. Hal ini memunculkan keluhan masyarakat mengenai pembayaran pelayanan kesehatan, bentuk pelayanan yang lebih bersifat birokratis dibandingkan waktu pelayanan pemegang kartu BPJS, Lokasi RS dan Puskesmas yang menjadi rujukan pelayanan KIS dan sebagainya. Satu hal yang perlu mendapat perhatian bersama adalah bagaimana perubahan kebijakan tidak terkesan berdampak pada penurunan kualitas pelayanan kesehatan bagi masyarakat miskin serta tetap menjamin kemudahan akses kesehaan bagi masyarakat miskin.

B. Rumusan Masalah.

Dari latar belakang tersebut, pertanyaan penelitian dirumuskan sebagai berikut:

1. Bagaimana aksesabilitas dan kualitas pelayanan kesehatan keluarga miskin di kecamatan Mojosonga, Boyolali ?

2. Bagaimana kapabilitas petugas pelayanan kesehatan bagi keluarga miskin di kecamatan Mojosonga, Boyolali

3. Bagaimana strategi pemerintah daerah untuk mengimplementaskan kualitas pelayanan kesehatan bagi Keluarga miskin?

C. Tujuan Penelitian

1. Untuk mengetahui akses pelayanan kesehatan keluarga miskin di kecamatan

mojosonga, Boyolali.

2. Untuk mengetahui tingkat kapabilitas petugas pelayanan kesehatan bagi keluarga

miskin di kecamatan mojosonga, boyolali

3. Untuk mengetahui bagaimana strategi pemerintah daerah dalam mengimplementasikan

kebijakan publik terkait dengan kualitas pelayanan kesehatan bagi keluarga miskin

D. Luaran yang diharapkan

1. Artikel ilmiah di jurnal refanas

\section{TINJAUAN PUSTAKA}

\section{A. Akses Pelayanan Kesehatan Keluarga Miskin}

Dalam perspektif sosial ekonomi sudah banyak kajian yang mengungkapkan bagaimana tingkat kesejahteraan yang diraih oleh masyarakat dan rumah tangga miskin. Asumsi sederhana untuk menggambarkan tingkat kesejahteraan dan kemiskinan yang sudah banyak dikenal antara lain dilihat dari perspektif tingkat pendapatan dan konsumsi rumah tangga. Pendekatan teoritis seperti ini misalnya kita jumpai pada teori kemiskinan dan teori kelas sosial, sebuah teori yang menyandarkan diri pada aspek behavioral dan struktur sosal(Sherraden 2006:46). Secara sederhana teori tersebut dipilah menjadi dua kategori yaitu yang terfokus pada tingkah laku individu dan teori yang cenderung bermuara pada struktur sosial. Teori struktural mengungkapkan bagaima individu mengalamikesulitan untuk keluar dari jerat kemiskinan karena harus berhadapan dengan dinding tembok yang sistemik sedemikian rupa sehingga sistem tersebut menciptakan ketidaksamaan dalamkesempatan yang berkelanjutan dalambentuk penindasan terhadap kelompok miskin. Pada banyak kasus ketidaksamaan dalam kesempatan juga terjadi pada kesempatann untuk mendapatkan akses pelayanan kesehatan. Lebih tepatnya kualitas pelayanan kesehatan yang diberikan kepada masyarakat miskin sangat memprihatinkan. Ada sikap apriori terhadap kelompok miskin dalam memperoleh akses layanankesehatan di puskesmas, rumah sakit umum maupun rumah bersalin dan sejenisnya yang ditandai dengan simbol simbol subsidiritas seperti BPI JKN KIS Sementara itu dalam perspektif yang berbeda yaitu melalui pendekatan ekonomi makro, konsep kemiskinan lebih banyak disebabkan oleh faktor internal seperti produktifitas yang rendah dibarengi dengan tingkat konsumsi yang rendah pula, kinerja yang rendah dan kesehatan yang rentan terhadap penyakit, tingkat pendidikan yang tidak memadai. Faktor -faktor tersebut secara akumulatif akan membentuk struktur masyarakat yang berpendapatan rendah, investasi dan tabungan nasional rendah pula. Keterkaitan diantara beberapa faktor seperti yang disebutkan di atas dikenal dengan istilah 
lingkaran setan kemiskinan (Nasution 2002;30). Untuk bisa keluar dari lingkaran kemiskinan tersebut perlu adanya sentuhan eksternal misalnya diperlukan kebijakan yang bersifat subsidiritas.

\section{B. Perspektif Kebijakan dan Pelayanan Publik}

Pemahaman tentang kebijakan publik dalam penelitian ini, disepadankan dengan kebijakan negara yaitu dengan mengikuti teori Thomas Dye, kebijakan negara dipahami sebagai "is whatever goverments choose to do not to do " maksudnya Apapun yang dipilih pemerintah untuk dilakukan atau tidak dilakukan Islamy (2007: 18). Serta studi kebijakan negara antara lain mencakup evaluasi dampak kebijakan negara pada masyarakat, baik berupa dampak yang diharapkan (yang direncanakan) maupun dampak yang tidak diharapkan.

Kualitas pelayanan publik sedikit banyak akan ditentukan oleh tingkat kompetensi dari pihak yang emberikan pelayanan itu sendiri. Demikian pula dengan kemudahan maupun hambatan hambatan akses pelayanan kesehatan akan berhubungan langsung dengan aparatur pemerintah atau birokrat di tingkat bawah yang langsung berhadapan dengan masyarakat dalam menjalankan fungsi pelayanan tersebut. Masyarakat miskin yang pernah mendapatkan akses pelayanan kesehatan dari dokter rumah sakit, bidan yang membantu persalinan maupun petugas puskesmas yang melayani masyarakat penggunan KIS akan membentuk persepsi tersendiri terhadap kualitas pelayanan kesehatan yang diterimanya terlebih lagi jika pada saat yang sama aparat juga harus memberikan pelayanan sejenis terhadap masyarakat umum yang tidak mendapatkan program subsidiritas pelayanan kesehatan. Ada beberapa aspek yang turut menentukan pembentukan kompetensi seseorang dalam menjalankan profesinya sebagai pelayan publik antara lain orientasi kecakapan, kemampuan untuk berfikir analitis dan konseptual, orientasi layanan publik, pengembangan lainnya, penginstruksian, fleksibilitas, dampak dan pengaruhnya, upaya pencarian informasi yang dibutuhkan, inisiatif, integritas, pemehaman interpersonal, komitmen pada organisas, tingkat kesadaran berorganisasi, kemampuan menjalin relasi, rasa percaya diri, kepemimpinan kelompok serta kerjasama dalam kelompok. Sedarmayanti (2007). disamping itu secara normatif juga ada aspek lan yang diyakini turut memberi kontribususi publik terhadap kualitas pelayanan publik seperti aspek kebijakan organisasi..

Pemerintah kabupaten boyolali sebagai organisasi publik mempunyai tugas dan fungsi pelayanan antara lain pelayanan kesehatan yang mencakup kelompok masyarakat miskin kebijakan pelayanan kesehatan bagi masyarakat kabupaten Boyolali tertuang dalamPerda no 11 tahun 2018 tentang Tarif kesehatan klas III pada RSD Pandan Aran Boyolali dan Perda no.5 th 2014 tentang jaminan kesehatan daerah kabupaten Boyolali yang mengatur tentang JAMKESDA serta implementasi kebijakan tentang program BPJS KIS dari program pemerintah pusat.akses pelayanan keluarga miskin akan terlihat dari persepsi masyarakat, iskin itu sendiri terhadap kualitas pelayanan yang diterima oleh karena itu peningkatan kualitas pelayanan kesehatan secara terus menerus perlu ditingkatkan dengan cara meningkatkan manajemen kuakitas pelayanan publik di bidang kesehatan

Pada dasarnya kebijakan pemerintah tentang penetapan kewenangan wajib dan standar

pelayanan minimal (SPM) bidangkesehatan mengacu pada kebijakan dan staregi desentralisasi bidang kesehatan. Tujuanstrategis pelaksanaan desentralisasi bidang kesehatan yang erat kaitannya denganmenetapan kewenangan wajib dan SPM Bidang Kesehatan, adalah: (1) Terbangunannya komitmen antara pemerintah, legislatif, masyarakat dan stakeholderlainnya guna kesinambungan pembangunan kesehatan. (2) Terlindunginya kesehatan masyarakat, khususnya penduduk miskin, kelompokrentan, dan daerah miskin. (3) Terwujudnya komitmen nasional dan global dalam program kesehatan. USAID (2008:1)

SPM juga diapakai sebagai salah satu acuan dalam pencapaian Millenium Development Goals (MDGs) dimana salah satu instrumen sekaligus indikator dasar untuk mengoptimalkan pelayanan dasar sebagi tugas dan fungsi pokok yang diperankann oelh pemerintah. Diantara pelayanan dasar yang dikategorikan dalam konteks kekinian salah satunya adalah pelayanan kesehatan dan lingkungan termasuk penetaan lingkungan kumuh seperti MCK, Hidrant umum, jalan2 d. setapak/gang2), tata kota/ tata bangunan, taman, kebersihan, kesehatan lingkungan (polusi, penyakit menular, penyakit yang ditularkan binatang; rabies, malaria, pes dsb), sewage/saluran limbah, persampahan, penerangan jalan, pemeliharaan sungai. Miftah (2009:13)

Sementara itu Parasuraman (1985:42) melakukan tinjauan terhadap konsep kualitas pelayanan

publik dari variabel pelayanan yang dirasakan (perceived service) dan variabel pelayanan yang diharapkan (expected service).Perceived service lebih banyak ditentukan oleh penentu kualitas 
pelayanan yang diukur melalui 10 indikator yaitu reliability (keandalan), responsiveness (ketanggapan), competence (kemampuan), access (mudah diperoleh), courtsey (keramahan), communication (komunikasi), credibility (dapat dipercaya), security (keamanan), understanding/knowing the customer (memahami pelanggan) dan tangibles (bukti nyata). Sedangkan Expected Service (pelayanan yang diharapkan) bergantung pada WOM (Word of Mouth), Personal Needs dan Past Experience. Perbandingan antara kualitas pelayanan yang diharapkan dengan kulitas pelayana yang didapatkan pada gilirannya akan memunculkan Perceived Service Quality (kualitas pelayanan yang dirasakan). Parasuraman membuat sejumlah kriteria umum atau standar yang digunakan oleh masyarakat dalam menentukan kualitas pelayanan jasa ke dalam lima dimensi meliputi tangibles, reability, responsiveness, assurance dan empaty.

\section{KERANGKA BERPIKIR}

Pelayanan kesehatan bagi keluarga miskin yang baik tidak terlepas dari kebijakan publik yang mengatur tentang standrat pelayanan minimal yang harus disediakan oleh aparat pemerintah setempat termasuk tenaga medis seperti dokter,bidan, perawat maupun petugas administrasi yang berhadapan langsung dengan pelayanan masyarakat perlu memahami adanya aturan atau norma yang jelas bagi petugas mengenai pekerjaan mereka agar bisa memberi pelayanan kesehatan yang optimal bagi masyarakat miskin khususnya dan masyarakat umum. Adanya kebijakan pemerintah daerah yang sering kali tumpang tindih dengan kebijakan pemerintah pusat akan mempengaruhi kualitas pelayanan dikarenakan implementasi kebijakan sulit untuk diterapkan sesuai dengan kondisi wilayah masing masing.Jika hal ini terjadi maka masyarakat yang merasa dirugikan dalam mendapatkan akses pelayanan kesehatan.seperti perubahan program pemerintah dari ASKESKIN menjadi Badan Penyelenggara Jaminan Sosial melalui Jaminan Kesehatan Nasional ke kartulndonesia sehat menimbulkan persoalan tersendiri bagi aparat pemerintah daerah dalam memberi layanan kesehatan

Didasarkan hasil onservasi dilokasi penelitian serta didukung oleh kajian pustaka maka secara garis besar kerangka berpikir penelitian tentang akses pelayanan kesehatan masyarakat miskin bisa disusun seperti bagan yang tersaji di bawah ini :

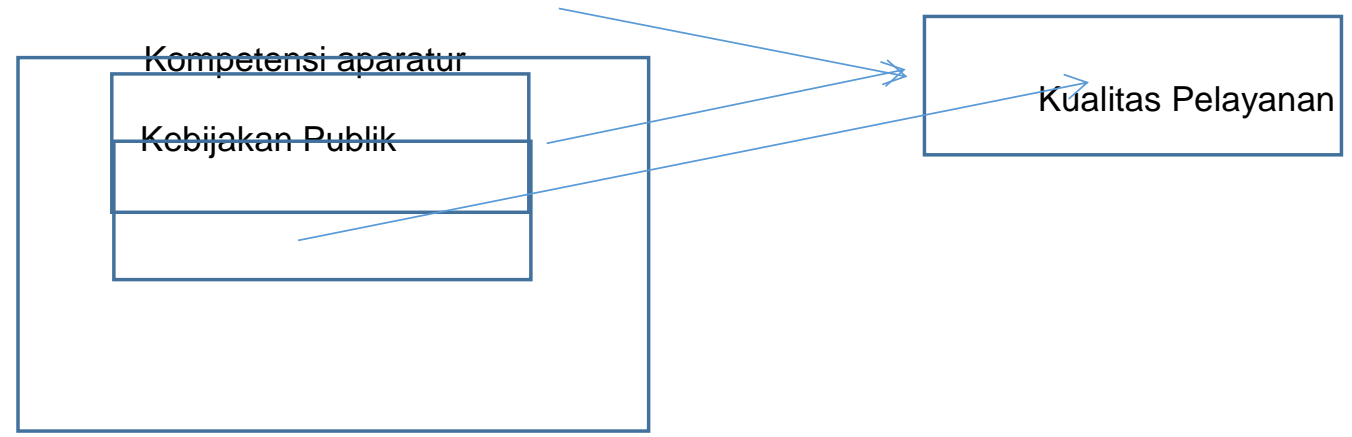

\section{D.Roadmap Penelitian}

Penelitian mengenai kebijakan publik terutama terkait dengan implementasi kebijakan sudah

banyak dilakukan. Seperti hasil penelitian dari Dennis $P(2000)$ strategi kebijakan untuk menanggulangi kesehatan lingkungan masyarakat urban. Sementara itu Ding Yan, Smith, Helen et al (2013) meneliti kebijakan publik bidang kesehatan dalam perspektif berbagai faktor yang mempengaruhi pelayanan kesehatan di China. Namun demikian hasil penelitian tesebut belum menyentuh pada aspek aksesabilitas masyarakat miski, sehingga penelitian yang terfokus pada akses pelayanan masyarakat miskin masih penting dan relevan diteliti pada saat ini. Sebagai gambaran tentang kebaharuan penelitian ini dapat dilihat dari bagan yang tersaji di bawah ini: 


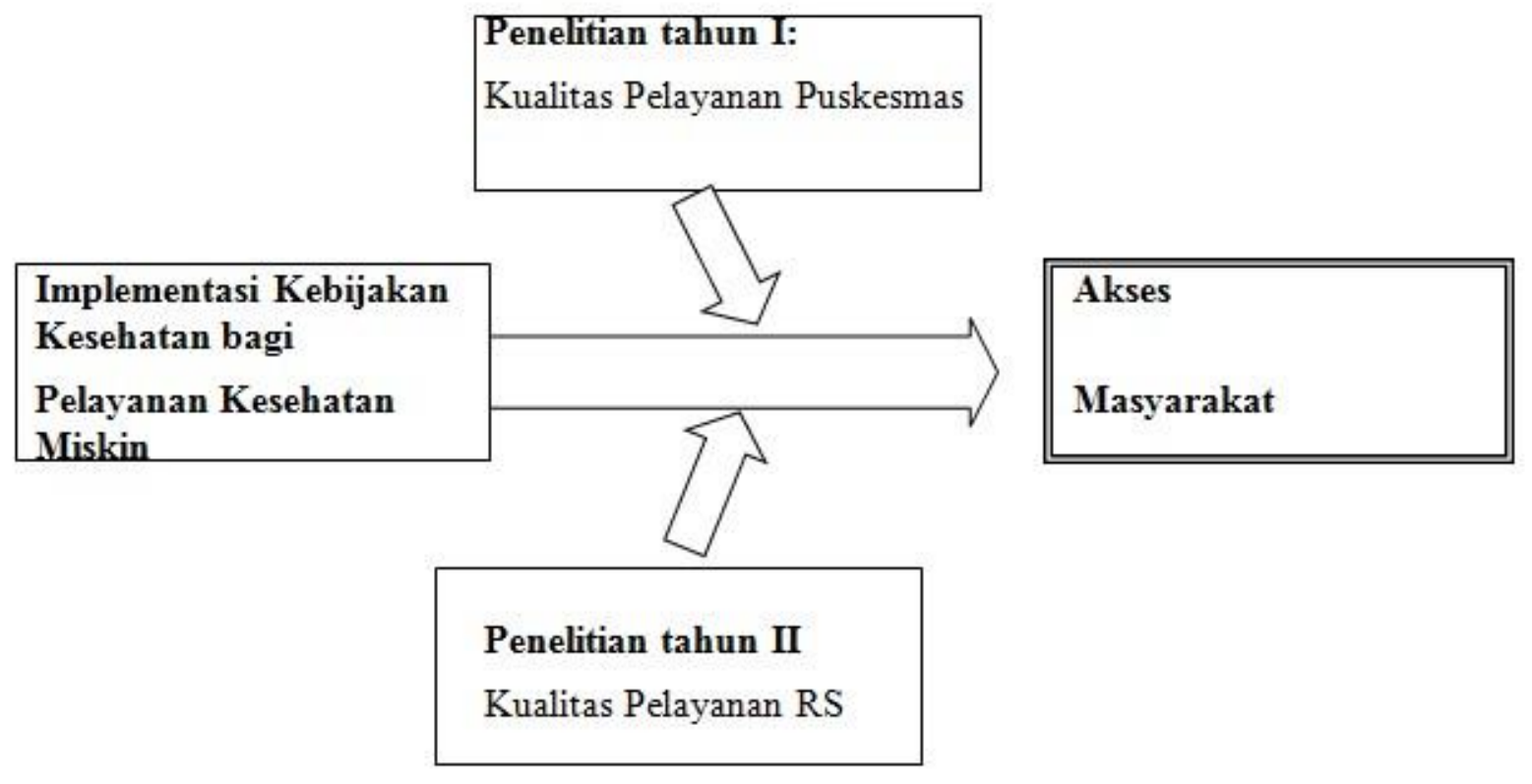

\section{METODE PENELITIAN}

\section{A. Jenis Penelitian dan Lokasi Penelitian}

Penelitian ini dilakukan dalam perspektif deskriptif kualitatif di mana hasil penelitian dipaparkan dalam bentuk data naturalistik, fakta berupa diskripsi hasil observasi maupun keterangan yang berasal dari sumber informasi yang kompeten, serta informasi pendukung lain yang mampu memberikan jawaban tentang sejauh mana keberpihakan pemerintah daerah dalam memberika kualitas pelayaan kesehatan kepada masyarakat miskin melalui kebijakan publik bidang kesehatan.

Penelitian dilaksanakan di kecamatan Mojosonga,Kabupaten Boyolali, salah satu kabupaten

dalam wilayah Propinsi Jawa Tengah.Desa Dlingo berbatasan dengan kecamatan Kaliwungu kabupaten semarang dan desa Brajan kecamatan mojosongo kabupaten boyolali.

Kabupaten Boyolali dengan slogan Boyolali Tersenyum (Tertib,Elok,Rapi, Sehat,Nyaman untuk masyarakat) merupakan wilayah yang memiliki pariwisata dengan panorama gunung Merapi dan gunung merbabu dan mendapat julukan kota sapi, Nieuw Zeelandvan java, kota susu Smile of Java, serta pusat pengembangan pelayanan publik yang manusiawi sarat dengan nilai nilai budaya, antara lain dengan kebijakan pembangunan pasar tradisional yang lebih sehat, lebih humanistis, pengembangan ruang publik yang berwawasan ekologi manusia seperti pemanfaatan lahan kosong sebagai taman rekreasi, pengembangan pesat-pusat pelayanan publik seperti terminal dengan lebih mengedepankan kualitas pelayanan publik dan sebagainya.

\section{B. Rancangan Penelitian}

Penelitian ini berusaha mengekplorasi tiga konsep utama untuk keperluan analisis akses

pelayanan kesehatan masyarakat miskin yaitu kompetensi petugas pelayanan kesehatan, Kebijakan Publik terkait dengan pelayanan kesehatan untuk masyarakat miskin, dan konsep tentang kualitas pelayanan kesehatan. Beberapa indikator untuk melihat tingkat kompetensi pelayanan kesehatan antara lain bisa dikenali dari pendidikan formal, pendidika dan pelatihan yang pernah diikuti, pengalaman kerja petugas pelayanan kesehatan, serta ketrampilan dasar yang dimiliki masing-masng petugas pelayanan 
kesehatan. Kebijakan Publik dilihat dari empat indikasi yaitu kebijakan pimpinan Puskesmas maupun kebijakan Organisasi pelayanan kesehatan (RS), Kondisi dan lingkungan kerja, intensif kerja serta mutasi aparatur daerah. Sedangkan konsep kualitas pelayanan publik diindikasikan dari aspek tangibilitas, reabilitas, responsibilitas, kompetensi, empati dan akuntabilitas.

\section{Populasi dan Sampel}

Populasi pada penelitian ini adalah seluruh warga masyarakat miskin di kecamatan Mojosonga, Boyolali yang menjadi anggota PBI JNK KIS yang pernah menerima layanan publik dari lembaga pelayanan kesehatan dalam jajaran pemerintah kabupaten Boyolali. Penentuan sampel diambil dari anggota populasi guna mendapatkan data primer tentang aksesabilitas masyarakat miskin di bidang pelayanan kesehatan. Sampel yang diambil adalah sampel yang mewakili informasi yang dibutuhkan tersebut yaitu semua keterangan yang berasal dari sumber data yang pernah langsung berhubungan atau pernah mengalami, merasakan sekaligus memiliki persepsi tentang kualitas pelayanan publik bidang kesehatan dari instansi pemerintah kabupaten Boyolali . Penetapan sampel dilakukan dengan pertimbagan - pertimbangan tertentu (purposive sampling) sesuai dengan jumlah dan jenis informasi yang diperlukan dalam konteks kemudahan akses pelayaan publik masyarakat miskin. Sumber data primer yang ditetapkan sebagai key informan dan informan penelitian birokrat pemerintah kabupaten Boyolali yang terlibat langsung dengan pelayanan kesehatan masyarakat miskin antara lain dari jajaran dinas kesehatan, rumah sakit, rumah bersalin, puskesmas serta masyarakat miskin yang pernah mendapatkan pelayanan kesehatan program PBI JKN KIS

\section{JENIS DATA DAN SUMBER}

1. Data primer berupa semua jenis informasi yang bersumber dari informan dan informan kunci dengan kreteria yang telah ditentukan sebelumnya.

2. Data sekunder berupa data tertulis yang di dapat dari catatan dan dokumen yang ada

\section{E. TEHNIK PENGUMPULAN DATA}

\section{Observasi lapangan}

Pengumpulan data dimulai pada saat peneliti melakukan observasi awal penelitian yaitu melakukan pengamatan pelayanan kesehatanbagi keluarga miskin di kecamatan mojosongo ,Boyolali 2. Wawancara mendalam

Mengumpulkabn data primer melalui wawancara secara mendalam kepada informan 3. Arsip dokumen tertulis

\section{F. ISTRUMEN PENELITIAN}

Pengumpulan data awal dilakukan dengan melakukan observasi di lokasi penelitian baik di puskesmas maupun terhadap masyarakat setempat yang pernah mengunakan jasa pelayanan kesehatan di puskesmas tersebut dengan cara di catat dan tanya jawab.

\section{G. PENGOLAHAN DATA DAN ANALISA DATA}

Tahap pengolahan data dimulai sejak dilakukan observasi ke lapangan. Informasi yang akan dianalisis pada tahapan ini adalah semua data yang dijaring dari sumber data utama dan sumber data pendukung baik untuk keperluan pengidenfitikasian masalah, untuk perumusan masalah, untuk membuat rancangan penelitian, penetapan lokasi penelitian serta informasi yang terkait dengan konsepkonsep utama yang digunakan dalam keseluruhan proses penelitian. Bersamaan dengan kegiatan pengumpulan data pendukung lainnya, semua data yang telah berhasil dikumpulkan pada setiap tahap peneltian dan setelah dilakukan pengecekan ulang, untuk menjamin validitas sehingga diyakini data tesebut tidak akan mengalami perubahan lagi, data seperti itu dipisahkan dari data mentah lain untuk dianalisis. Jika ada data yang dinilai kurang lengkap, bertentangan dengan data lain, dan tidak memiliki kejelasan dengan konteks permasalahan yang diteliti maka data tersebut akan dikonfirmasikan dengan sumber data pendukung lainnya. Proses tersebut dilakukan terus menerus sampai mencapai titik redundancy. Pada dasarnya kegiatan analisa data terdiri dari tiga alur kegiatan yaitu reduksi data, penyajian data dan penarikan kesimpulan sementara serta verifikasi (Miles 1992). 
Reduksi data, dilakukan dengan maksud untuk menyederhanakan dan mentransformasikan semua catatan - catatan informasi tertulis yang terfragmentasi dan muncul selama penelitian guna membentuk analisa yang tajam dengan menggolongkan, mengarahkan, membuang data yang tidak perlu, serta mengorganisir data sedemikian rupa sehingga memudahkan untuk menarik kesimpulan sementara maupun kesimpulan akhir pada saat semua data mutakhir sudah tersaji. Semua data yang sudah terkumpul dan sudah direduksi menurut keperluan penelitian, alur kegiatan analisa selanjutnya adalah menyajikan sekumpulan data yang telah tersusun sehinga memungkinkan untuk mempermudah orang menangkap makna setiap fenomena yang diteliti.

Setelah data disajikan ke dalam bentuk teks naratif, kegiatan analisa berikutnya adalah menarik kesimpulan sementara dan memverifikasikan kesimpulan tersebut.Pada akhirnya kesimpulan akhir yang ditetapkan harus selalu diverifikasi dengan meninjau ulang catatan data di lapangan, sehingga setiap makna yang muncul dari data benar-benar teruji kebenarannya dan kecocokannya.

Pengolahan data dilakukan dengan fokus memahami kelemahan dan kemudahan akses pelayanan kesehatan bagi masyarakat miskin kecamatan mojosanga peserta KIS melalui kebijakan program JKN (jaringan Kesehatan Nasional). Pengolahan data dilakukan dalam rangka mencari sebab utama yang menjadi permasalahan dalam penelitian maupun sebab sebab lain yang melatar belakangi persoalan penelitian. Semua data yang terkumpul diolah dan diinterpretasikan guna menemukan konsep-konsep pemecahan masalah dari sudut pandang sumber data.Semua data kualitatif yang sudah terkumpul berupa catatan catatan dan rekaman didiskripsikan secara sehingga dapat ditarik suatu kesimpulan yang spesifik.

Proses analisis data dilakukan secara terus menerus dari observasi awal penelitian sampai pada proses penelitian, bersamaan dengan proses pengumpula data. Antara data pendukung variabel utama dan faktor yang mempengaruhinya selalu terjalin dan berinteraksi baik pada waktu melakukan reduksi data, sajian data maupun verifikasi untuk menemukan kesimpulan. Ketiga proses ini dilakukan mulai dari observasi untuk menyusun proposal penelitia, pengumpulan data primer dan proses penulisa laporan hasil penelitian. Sutopo $(2006: 119)$

\section{PEMBAHASAN}

\section{A.Profil Kecamatan Mojosonga Boyolali}

Visi Kabupaten Boyolali yang ditetapkan adalah "Pro Investasi

Mewujudkan Boyolali yang Maju dan Lebih Sejahtera". Visi tersebut ingin mewujudkan kondisi masyarakat yang semakin sejahtera, serta kondisi yang semakin kondusif dan modern dengan tetap memperhatikan lingkungan berkelanjutan demi kemajuan perindustrian, perdagangan dan jasa, dan hal ini tidak lepas dari masyarakat yang sehat. Segenap komponen bangsa bertangggung jawab untuk memelihara dan meningkatkan derajat kesehatan individu, keluarga, masyarakat beserta lingkungannya. Setiap program Kesehatan harus mampu membangkitkan peran serta individu, keluarga dan masyarakat sedemikian sehingga setiap individu, keluarga dan masyarakat dapat menolong dirinya sendiri. Dengan dasar ini, setiap individu, keluarga dan masyarakat melalui program kesehatan difasilitasi agar mampu mengambil keputusan yang tepat ketika membutuhkan pelayanan kesehatan. Warga masyarakat harus mau bahu membahu menolong siapa saja yang membutuhkan pertolongan agar dapat menjangkau fasilitas kesehatan yang sesuai kebutuhan dalam waktu yang sesingkat mungkin. Di lain pihak, fasilitas pelayanan kesehatan yang ada perlu terus diberdayakan agar mampu memberikan pertolongan kesehatan yang berkualitas, terjangkau, sesuai dengan norma sosial budaya setempat serta tepat waktu, adil dan merata Setiap individu, keluarga dan masyarakat mempunyai kesempatan yang sama untuk memperoleh pelayanan kesehatan yang dibutuhkan sehinggaProfil Kesehatan Kabupaten Boyolali 2018 dapat mencapai derajat kesehatan yang Puskesmas mojosonga yang terletak di jalan raya solo semarang,kecamatan mojosonga Boyolali menempati tempat yang strategis,Keberadaan puskesmas mojosongo sampai th 2018 ditujang oleh dr umum , dr gigi, bidan dan tenaga kesehatan. Didalam memberi layanan kesehatan puskesmas mojosongo yang berada diluar dibantu dengan posyandu dan pos lansia yang ada ditiap tiap RT/Rw.

B. Kualitas Kesehatan Masyarakat Mojosonga

Kualitas kesehatan masyarakat mojosongadapat dilihat dari hasil pencapaian layanan kesehatan masyarakatyang dilakukan oleh pemerintah melalui puskesmas.data hasil temuan penelitian tentang hal tersebut diatas di kecamatan mojosonga tersebut dianalisa berdasarkan penyebaran wilayah 
dengan indikator yang digunakan untuk mengukur standar pelayanan minimum dibidang kesehatan indikator yang digunakan untuk menganalisa data adalah indikator indonesia sehat sandar pelayanan minimal bidang kesehatan berdasarkan Permenkes RI no 43 Th 2016 tentang pelayanan kesehatan.Idikator tersebut meliputi perilaku kesehatan, kesehatan lingkungan, pelayanan kesehatan dan manajemen kesehatan

Gambaran umum tentang kualitas kesehatan kecamatan mojosonga th 2018

\begin{tabular}{|l|l|l|l|}
\hline No & Indikator & Sub indikator & jumlah \\
\hline 1 & Kematian Bayi & Bayi lahir & 407 \\
& & Bayi Meninggal & 12 \\
\hline 2 & Jumlah Balita & Balita & 3151 \\
& & Balita Gisi buruk & 0 \\
\hline 3 & Cakupan Imunisasi & DPT-HB3 & 915 \\
& & Polio & 915 \\
& & Campak & 915 \\
\hline
\end{tabular}

Sumber data :www.kemkes.go.id. Profil Kesehatan Kabupaten Boyo;ali 2018

Melihat hasil tabel diatas data tersebut merefleksikan perkembangan pelayanan terhadap akses kesehatan di puskesmas mojosongo, kabupaten Boyolali,dilihat dari sub indikator jumlah balita yang ada di kecamatan boyolali sejumlah 3151 dan sudah tidak ada yang menderita gisi buruk, dan masyarakat sudah mulai sadar akan imunisasi untuk balita sehingga menyebabkan harapan hidup di kecamatan mojosonga semakin tinggi

C. Akses Kesehatan masyarakat miskin

\section{1, Masyarakat Miskin}

Kemiskinan adalah keadaan saat ketidak mampuan untuk memenuhi kebutuhan dasar seperti makanan, pakaian tempat berlindung, pendidikan dan kesehatan. BPS mendefinisikan kemiskinan kemampuan memenuhi kebutuhan dasar .dengan pendekatan ini kemiskinan dipandang sebagai ketidak mampuan seseorang dari sisiekonomi untuk memenuhi kebutuhan dasar makanan,jadi penduduk miskin adalah mereka yang memiliki rata - rata pengeluaran perkapita di bawah garis kemiskinan. Sedangkan garis kemiskinan adalah konsep yang sering digunakan untuk menilai derajat kemiskinan masyarakat.di Indonesia kosep garis kemiskinan dirilis oleh biro pusat statistik dan badan perencanaan keluarga berencana dengan konsep mengklasifikasikan masyarakat miskin dengan label keluarga pra sejahtera dan keluarga sejahtera.

\section{Pelayanan Kesehatan Di Puskesmas Mojosonga}

\section{A. Pelayanan Kesehatan Ibu}

A, 1Pelayanan yang diberikan mulai dari standar yaitu pelayanan ibu hamil minimal harus periksa pada teri semester yang dilakukan oleh bidan pelayanan ini meliputi :

Tibang berat badan, ukur tekanan darah, nilai status gizi, ukur tekanan darah, nilai status gisi,ukur tinggi puncak rahim, tentukan presentasi janin dan detak jatung janin,pemberian imunisasi tetanus toksoid, tes hb dan tes laboratorium bila diperlukan.

A.2 Pelayanan ibu melahirkan dilakukan oleh bidan. Standart persalinan normal diatur oleh peraturan mentri kesehatan no.97 th 2014 tentang pelayanan kesehatan masa sebelum hamil, masa hamil persalinan dan masa sesudah persalinan ,penyelenggaraan kontrasepsi,serta pelayanan kesehatan 
seksual. Adapun untuk persalinan dengan komplikasi mengikuti acuan dari buku saku pelayanan kesehatan ibu di fasilitas rujukan.terkait dengan pelayanan ini karena puskesmas mojosonga belum memiliki dr kandungan dan tempat untukrawat inap maka pasien akan dirujuk ke rs rujuan.

B. Pelayanan kesehatan Balita

B.1 Pelayanan bayi usia 0 - 28 hari

Mengacu pada Neonatal esiensial sesuai yang tercantum dalam peraturan mentri kesehatan no. 25 th 2014 tentang upaya kesehatan anak dilakukan oleh bidan, perawat atau dokter atau dr spesialis anak yang memiliki surat tanda register.

B.2 Pelayanan Kesehatan Balita.

peraturan mentri kesehatan no.25 th 2014 tentang upaya kesehatan anak dilakukan oleh bidan, perawat atau dokter atau dr spesialis anak yang memiliki surat tanda register. Meliputi penimbangan, pengukuran tinggi badan, pemberian imunisasi DPT-HB3, Polio,Campak dan imunisasi dasar lengkap B.3 Pelayanan Kesehatan pada usia pendidikan dasar

Penjaringan kesehatan yang diberikan kepadaanak usia pendidikan dasar minimal satu kali dalam setahun oleh puskesmas meliputi :

1. Penilaian status gizi.

2. Penilaian tanda vital

3. Penilaian kesehatan gigi dan mulut

4. Penilaian ketajaman indera pendengaran dengan garpu tala

5. Penilaian ketajaman indera penglihatan dengan poster snellen

Definisi operasional capaian kinerja dinilai dari cakupan pelayanan kesehatan pada usia pendidikan dasar di wilayah kecamatan mojosonga dalam kurun eaktu satu tahun.

C. Pelayanan Kesehatan di usia Produktif ( 15 s/d 59 Th )

Pelayanan skrining kesehatan yg diberikan, sesuai ,kewenanganya ,dokter , bidan , perawat, tenaga gizi dan petugas pelaksana posbindu terlatih meliputi

1 deteksi kemungkinan obesitas.

3. Deteksi hipertensi

4. Deteksi diabetes melitus

5. Deteksi gangguan metal rmosional

6. Ketajaman penglihatan

7. Ketajaman pendebgaran

8. Kanker payudara

9. Iva khusus untuk umur $30-59$ th 
Jika terjadi kelainan maka akan dirujuk ke RS rujukan definisi capaian dinilai dari kinerja yang mendapat pelayanan srining kesehatan sesuai standar di wilayah kerja dalam kurun waktu tertentu

D. Pelayanaan usia lanjut

Setiap warga Indonesia yang berumur 60 th keatas yang disebut lansia mendapatkan skrining kesehatan sesua standrat yang dilakukan oleh petugas yang sesuai dengan kewenanganya dokter,bidan,perawat,nutrisi/ tenaga gizi dan kader posyandulansia/posbindu yang ada disetiap RW. Pelayanan tersebut meliputi :

1. Pelayanan skrining kesehatan minimal 1 tahun sekali

2. Deteksi hipertensi

3. Deteksi diabetes melitus

4. Deteksi kadar kolestrol darah

5. Deteksi gangguan mental emosi dan perilaku, termasuk kepikunan yang ditest dengan cara menggunakan mini cog atau mini mental status examination ( MMSE )/(AMT) dan geniatric depression scale ( GDS)

Pasien lansia yang ditemukan memiliki faktor resiko wajib dilakukan intervensi secara dini dan jika ditemukan penderita penyakit wajib ditangani atau dirujuk ke rumah sakit rujukan.

\section{E. Pelayanan kesehatan penderita Hipertensi}

Sasaran adalah warga penduduk yang berumur 15 th keatas, penderita hipertensi esensial . hipertensi tanpa komplikasi memperoleh pelayanan standrat dan upaya promosi kesehatan melalui modifikasi gaya hidup di fasilitas kesehatan tingkat pertama. Sedangkan penderita hipertensi dengan omplikasi jantung ,stroke ginjal kronis,dan diabetes melitus perlu dirujuk ke fasilitas kesehatan tingkat lanjut.

Standrat pelayanan penderita hipertensi meliputi :

1. Pemeriksaan dan monitoring tekanan darah,edukasu, pengaturan diet seimbang aktifitas fisik dan pengelolaan farmakologis

2. Pelayanan untuk mempertahankan tekanan darah pada $<140 / 90 \mathrm{mmHg}$ untuk usia dibawah 60 th dan $<150 / 90$ mmHG untuk penderita 60 th keatas untuk mencegah terjadinya komplikasi jantung, stroke.ginjal dan diabetus melitus.

Defisi operasional capaian kinerja dinilai dari presentase jumlah penderita hipertensi yang mrndapatkan pelayanan kesehatan sesuai standrat di wilayah kerjanya dalam kurun waltu satu rahun

F. Pelayanan kesehatan penderita Diabetus Melintus

Sasaran adalah warga penduduk yang, diabetus melintus tanpa komplikasi memperoleh pelayanan standrat dan upaya promosi kesehatan melalui modifikasi gaya hidup di fasilitas kesehatan tingkat pertama. Sedangkan penderita Diabetus melintus dengan komplikasi perlu dirujuk ke fasilitas kesehatan tingkat lanjut.

Standrat pelayanan penderita DM meliputi edukasi, aktifitas fisik,terapi nutrisi medis dan intevensi farmakologis 


\section{1. pemeriksaan $\mathrm{HbA} 1 \mathrm{C}$}

Defisi operasional capaian kinerja dinilai dari presentase jumlah penderita DM yang mrndapatkan pelayanan kesehatan sesuai standrat di wilayah kerjanya dalam kurun waltu satu tahun

G. Pelayanan kesehatan jiwa dengan gangguan jiwa berat

Standrat pelayanan penderita ODGJ adalah :

1. pelayanan promotif preventif yang bertujuan meningkatkan kesehatan jiwa

ODGJ berat dan mencegah terjadinya kekambuhan dan pemasungan. Pelayanan ini diberikan oleh dokter dan perawat di wilayah kerjanya.

2. Pemberian edukasi dan evaluasi tanda dan gejala gangguan jiwa, kepatuhan

minum obat dan informasi terkait obat, mencegah tindakan pemasungan,

kebersihan dirii, kegiatan olah raga aktifitas rumah tangga sederhana.

3. Pemberian buku kerja sederhana dan materi KIE

Defisi operasional capaian kinerja dinilai dari presentase jumlah penderita ODGJ yang mrndapatkan pelayanan kesehatan sesuai standrat di wilayah kerjanya dalam kurun waltu satu tahun

H.Pelayanan kesehatan penderita TB

Standrat pelayanan penderita TB adalah :

1. pelayanan dilakukan oleh tenaga kesehatan sesuai kewenanganya di puskesmas dan jaringanya dan di FKTL baik pemerintah maupun swasta.

2. Penegakan diagnosis TB, pemeriksaan pemantauan kemajuan pengobatan pada pengobatan yang intesif,pemberian obat anti Tuberkulosis,

3. Penyuluhan tentang gejala TB dan pemberian KIE untuk mencegah penularan Tb dengan penerapan etika batuk, pengendalian faktor resiko dan pemberian obat pencegahan.

4. Prinsip pelayanan Tb temukan, obati sampai sembuh

Defisi operasional capaian kinerja dinilai dari presentase jumlah penderita TB yang mrndapatkan pelayanan kesehatan sesuai standrat di wilayah kerjanya dalam kurun waltu satu tahun

H. Pelayanan kesehatan orang HIV.

Pelayanan ini diberikan pada ibu hamil,pasien TB,Infeksi menular seksual, transgender,penunguna napza dan binaan lembaga pemasyarakatan yang dilakukan oleh tenaga yang berwenang dalam hal ini adalah FKTP dan FKTL baik negeri atau swasta. Pelayanan kesehatan meliputi.

1. Upaya pencegahan pada orang yang memiliki resiko tertular dengan cara

penyuluhan informasi terkait HIV AIDS

2.Pemeriksaaan dengan mengunakan tes cepat HIV sesuai standart nasional yang telah ditetapkan.

Harus dilakukan minimal 4 kali pemeriksaan trisemester

Defisi operasional capaian kinerja dinilai dari presentase jumlah penderita HIV AIDS yang mrndapatkan pelayanan kesehatan sesuai standrat di wilayah kerjanya dalam kurun waltu satu tahun

Pelayanan Kesehatan yang Diharapkan oleh Masyarakat Miskin.

Bagaimana pelayanan kesehatan yang telah dirasakan oleh kelompok masyarakat miskin yang berdomisili di wilayah puskesmas mojosonga, dapat dicermati dari data primer yang diperoleh dari seorang informan yang secara rutin berobat dan mendapatkan terapi kesehatn di Puskesmas mojosonga.

AP (55 th), adalah informan yang secara rutin mendapat pelaayanan kesehatn di Puskesmas Mojosonga. Informan tersebut telah merasakan betul kemudahan akses kesehatan di Puskesmas mulai dari kemudahan pelayanan administrasi, kemudahan mekanisme untuk memperoleh Kartu Indonesia sehat (KIS), sampai beaya rawat inap di rumah sakit. Dengan kondisi ekonomi yang tergolong pas pasan dimana sumber pendapatan keluarga diperoleh dari gaji suami sebagai cleaning service di instansi swasta serta usaha membuka warung kecil - kecilan di pinggir jalan kampung , ibu ini harus menghidupi 4 orang anggota keluarga. Sementara itu dari rekam jejak medis, dia terdeteksi mengalami gangguan kesehatan yang berhubungan dengan hipertensi dan sudah mengarah pada gejala gagal ginjal. Disamping dia juga pernah menjalani rawat inap di dua rumah sakit yaitu pada saat menjalani melahirkan yang beresiko dilakukuan di RS Pandan aran Boyolali tanpa biaya. Karena dia menggunakan kartu KIS, 
Terkait dengan kualitas pelayanan administrasi, sumber data primer ini juga merasakan kemudahan pada saat mengajukan permohonan KIS. Prosedur dirasakan sangat sederhana karena semua dilayani secara kolektif melalui kader PKK di Kecamatan mojosonga. Sedangkan masyarakat yang tergolong keluarga miskin dapat mengajukan ID DTKS untuk mendapatkan KIS. Verifikasi formulir permohonan ID DTKS KIS biasanya membutuhkan waktu kurang lebih $2-3$ hari kemudian ada pemberitahuan dari kantor kabupaten siapa saja yang sudah dipastikan memperoleh KIS. Kemudian warga masyarakat yang berhak memegang KIS bisa diambil di bayan setempat.

Dari Sumber data primer pada penelitian ini diperoleh data yang valid bahwa sebenarnya masyarakat tahu persis kriteria masyarakat miskin yang seharusnya mendapatkan fasilitas pelayanan kesehatan seperti KIS dan bentuk subsidiritas lain seperti BLT, dan sejenisnya. Namun sering kali kriteria tersebut tidak selamanya bisa terpenuhi.

Penuturan informan,"Memang sebenarnya sudah ada rambu-rambu siapa saja warga masyarakat yang termasuk miskin sehingga berhak mendapatkan beberapa fasilitas. Seperti kondisi rumah biasa bukan bedinding tembok, masih menggunakan jamban umum, ketentuan besarnya penghasilan keluarga, dan yang terpenting harus mempunyai ID DTKS Kemudahan akses pelayanan kesehatan baik di rumah sakit maupun di Puskesmas, juga diakui oleh informan.

Sebelum beroleh dan menjalani rawt inap di rumah sakit, informan yang pernah menjadi pasien Puskesmas dan Rumah sakit tersebut menceritakan pengalamannya berobat. Kualitas pelayanan di Puskesmas Mojosonga dinilai sudah sangat bagus. Dengan membawa KTP,dan KIS, dia datang ke Puskesmas, terlebih dulu mengambil nomor antrian pendaftaran Jika pasien datang dengan duduk di atas kursi roda, sudah ada petugas medis Puskesmas yang langsung membantu memberikan pertolongan untuk untuk mengambil nomor antrian. Layanan kesehatan di Puskesmas Sangkrah dimulai dari jam 08.00 pagi. Berdasarkan data yang digali dari informan serta hasil observasi penelitian, ruang tunggu pasien cukup nyaman dan representatif. Sambil menunggu panggilan nomor antrian, di ruang tunggu pasien telah disedianan beberapa bacaan koran umum, brosur informasi kesehatan, layar proyektor audio visual yang menayangkan informasi kesehatan.

Selanjutnya, sesuai nomor antrian, pasien dipanggil oleh petugas medis untuk dilakuan pemeriksaan tensi tekana darah oleh dokter Puskesmas. Dari hasil pemeriksaan yang dilakukan oleh dokter, jika diperlukan pasien tersebut akan dirujuk ke rumah sakit untuk mendapatkan pelayanan kesehatan di rumah sakit. Selama menjalani proses pengobatan dan rawat inap, pasien pemegang KIS yang sudah membawa surat rujukan dokter puskesmas juga tidak dikenakan biaya apapun baik biaya pemeriksaan dokter, obat maupun tindakan operasi serta rawat inap semua gratis. Masih dari sumber yang sama, sebelum diberlakukan kartu KIS, untuk pendaftaran pelayanan rumah sakit, pasien dikenakan biaya $\mathrm{Rp} 7$ 500,-

Data primer yang diperoleh langsung dari informan menggambarkan bahwa pelayanan kesehatan di Puskesmas dan Rumah Sakit sudah sangat bagus. Namun demikian berdasarkan pengalaman informan selama menjalani perawatan di Puskesmas dan Rumah Sakit, masih ada beberapa hal terkait pelayanankesehatan yang masih bisa ditingkatkan kualitas pelayanannya. Misalnya pasien merasakan waktu pendaftaran agak mundur dan petugas kurang cekatan. Terkadang pasien merasakan petugas kesehatan kurang empati terhadap kondisi pasien dimana pada saatnya lokat pendaftaran mestinya sudah dibuka, masih terlihat petugas bercanda dengan temannya sehigga pasien merasakan pelayanan pendaftaran tidak tepat waktu.

Hal lain yang kurang dipahami oleh pasien, menurut informan adalah pada waktu pasien yang akan menjalani operasi dan rawat inap di Rumah Sakit. Terkadang pasien merasa dipersulit untuk mendapatkan kamar rawat inap karena harus mengantri. Pada hari - hari tertentu dimana ruang rawat inap penuh, pasien harus mengantri sampai ada pasien rawat inap lain yang sudah diperkenankan pulang ke rumah. Proses menunggu antrian kamar rawat inap dirasakan lama karena pemegang Kartu KIS hanya berhak mendapakan pelayanan rawat inap kelas 3 saja. Berbeda dengan BPJS Kesehatan dimana pasien bisa menikmati layanan rawat inap kelas 2 atau kelas satu dengan konsekuensi finalsial yang telah di teteapkan rumah sakit. Artinya di sini pemegang BPJS lebih banyak memiliki opsi untuk mendapatkan pelayanan rawat inap baik kelas 3,2 atau bahkan kealas 1. Untuk Pemegang KIS tetap tidak bisa pindah ke kelas 2 dan 1, dengan kata lain mereka harus antri untuk pendapatkan pelayanan kesehatan rawat inap kelas 3 . Jadi menurut informan, kesulitan mencari kamar rawat inap bagi pemegang 
KIS semata mata disebabkan ketidak tahuan pasien terhadap prosedur pelayana rawat inap pemegang kartu KIS.

Harapan lain dari informan sebagi pemegang kartu KIS adalah harapan akan adanya keterbukaan informasi tentang kemungkinan mendaptakan kartu KIS dari pemegang BPJS Kesehatan. Ada beberapa kasus di mana pemegang BPJS ingin berpindah ke kartu KIS namun sampai saat penelitian ini dilakukan belum ada jawaban kepastian dari Balai kota. Informan juga melihat ada beberapa warga miskin yang belum mnedapatkan KIS tetapi juga belum ada informasi yang jelas tentang kepastian untuk mendapatkan kartu tersebut. Informan menilai bahwa baik Puskesmas maupun rumah sakit dalam memberikan pelalayanan kesehatan tidak terkesan diskriminatif, tetapi informan juga berhadap ada semacam prioritas berdasarkan kronis penyakitnya.

\section{Akses Pelayanan Kesehatan yang Diterima Masyarakat Miskin.}

Kualitas pelayanan kesehatan bisa diukur dengan cara melihat kualitas pelayanan kesehatan dengan acuan standar Pelayanan Minimum bidang kesehatan yang diberikan oleh petugas kesehatan kepada masyarakat pengguna pelayanan kesehatan serta menilai bagaimana persepsi dan harapan masyarakat terkait dengan kualitas pelayanan kesehatan yang sudah diterimanya. Oleh karena itu untuk mengetahui kualitas pelayanan yang diberikan oleh petugas pelayanan kesehatan Puskesmas, dalam penelitian ini banyak menggali data primer dari informan yang bertugas sebagai pelayan kesehatan di Puskesmas Mojosonga AS (40th), seorang bidan yang dalam kesehariannya bertugas memberikan pelayanan langsung terhadap pasien yang berkunjung ke puskesmas serta sebagai petugas pelayan kesehatan dia terlibat secara aktif di tengah masyarakat untuk memberikan pelayanan sesuai Standar Pelayanan Minimum sebagai mana Permenkes RI nomor 43 Tahun 2016 Tentang SPM Bidang Kesehatan yang menjadi acuan pelaksanaan pelayanan kepada masyarakat. Dari duabelas poin SPM bidang pelayanan, di Puskesmas Mojosonga pada umumnya sudah dilaksanakan sesuai dengan aturan perundangan tersebut, bahkan berdasarkan data yang diolah dalam penelitian ini secara umum dapat disimpulkan bahkan pelayanan kesehatan di Puskesmas sudah berada di atas standat pelayanan minimum. Hanya saja karena beberapa alasan tertentu antara lain keterbatasan sarana dan prasarana yang dimiliki termasuk belum ada dokter kandungan yang ditempatkan di puskesmas Mojosonga maka untuk pelayanan kesehatan ibu persalinan belum bisa dilakukan. Khusus untuk pelayanan ibu bersalin dokter puskesmas Mojosonga akan membaeikan rujukan ke Rumah sakit rujukan

Hasil analisis data primer yang terkait dengan kualitas pelayanan yang diterima masyarakat miskin dari Puskesmas Mojosonga disajikan salam diskripsi singkat berikut ini.

Puskesmas Mojosonga pada waktu penelitian ini dilakuan masuk dalam klasifikasi Puskesmas tingkat pratama atau satu tingkat di bawah puskesmas Paripurna dan tiga tingkat di atas klasifikasi puskesmas Madya dan Dasar. Tingkat Paripurna belum bisa diraih Puskesmas Mojosonga mengingat samapi saat ini atau pada waktu penelitian dilakukan, rasio antara dokter dan pasien belum memadai serta belum memiliki fasilitas rawat inap maupun pelayanan ibu bersalin.

Pelayanan terhadap ibu hamil dilakukan $4 \mathrm{X}$ selama masa kehamilan yaitu pada tri semester $1,2,3$ sebayak 2kali.

Pelayanan ibu bersalin dilayani di tempat pelayanan rujukan dan apabila terdapat pasien resti misal hipertensi maka pada smt 3 akan dirujik ke RSUD.

Pelayanan kesehatan bayi usia $0-28$ hari dilakukan dalam bentuk program pelayanan Pos yandu oleh bidan puskesmas untuk memeriksa berat badan bayi, tinggi badan dan kepastian bayi mengkonsumsi ASI.

Pelayananan kesehatan balita dilakukan Puskesman dan secara periodik dilayani oleh kader PKK dan kader palyanan kesehatan di Posyandu. Tindakan media yang dilakukan antra lain penanganan diare dengan memberikan larutan oralit kepada balita. Melakukan ilmunisasi dasar tiap hari selasa meliputi : HBO,Polio,BSC, Portabiori ( PPT,Hepatitis, Migniitis,campak ).

Pelayanan Kesehatan Usia Pendidikan dasar. Implementasi kebijakan pelayanan dilakukan dengan program kunjungan ke sekolah - sekolah dalam rangka pemberian imunisasi DT = Defteri, tetanus untuk klas $1-3$ Sekolah Dasar. Program dilaksanakan, 2 kali dalam setahun. Dalam hal ini Puskesmas bekerjasama dengan pihak sekolah, kegiatan dimulai dengan sosialisasi orang tua murid di pertemuan komite sekolah. Jika ada anak yang tidak mau diimunisasi petugas datang dari rumah kerumah siswa tersebut untuk memberi motivasi dan sosialisasi kegunaan imunisasi, jika tetap menolak maka orang tua murid wajib membuat surat pernyataan disertai materai 6000 . 
Pelayanan usia produktif ( Umur 20 th -55 Th ) dilakukan di POSBINDU yang ada di RW dimana pelaksana petugas Puskesmas dibantu tim POSPINDU )dengan tugas memotivasi masyarakat untuk hidup sehat, diet gizi dan sebagainya. Pelayanan usia produktif meliputi General Cek up pada usia 40 Th, IVA Tes dilayani tiap hari kamis gratis. Demikian pula pemeriksaan gigi, konsultasi ahli gizi. Apabila ada yang menderita sakit mata Puskesmas akan memberi rujukan ke Rs rujukan Apabila ditemukan anggota masyarakat yang terdetiksi mengalami gangguan Sakit Jiwa maka akan di rujuk keRSUJ dan untuk pengobatan pada bulan berikutnya tanpa rujukan dan tanpa biaya. Apabila ada yanng terkena hipertensi, deabetes dirujuk ke Puskesmas, Juga melayani imunisasi TT untuk calon pengantin

Pelayanan kesehatan pada usia lanjut Pos Lansia diselenggarakan di tiap RW oleh petugas Puskesmas dibantu tim lansia. Pemeriksann meliputii, pengukuran lemak tubuh.

Penanganan Penyakit TBC. Penyakit ini dikenali dari gejala batuk berdahak 2 minggu berturut turut, tubuh tampak kurus, napsu makan berkurang. Jika ditemukan warga masyarakat yang mengalami gejala demikian maka penanggananya adalah dahak diperiksa di laboratorium setelah dinyatakan positip terkena TBC maka wajib berobat selama 6 bulan berturut turut selain itu diberikan TMT dari puskesmas berwujud susu, telur dan kacang hijau.

\section{KESIMPULAN}

Dari paparan analisis data sebagai mana yang disajikan pada bab sebelumnya dapat disimpulkan bahkan pelayana kesehatan di Puskesmas Mojosonga sudah melampaui Standar Pelayanan Minimum bidang kesehatan sebagai mana Permenkes RI nomor 43 Tahun 2016 Tentang SPM Bidang Kesehatan sebagai acuannya. Indikator tersebut meliputi perilaku kesehatan, kesehatan lingkungan, pelayanan kesehatan dan manajemen kesehatan. Namun demikian masih ada satu item bidang pelayanan yang belum bisa dilaksanakan yaitu pelayanan ibu bersalin. Hal ini dikarenakan keterbatasan sarana dan prasarana termasuk belum tersedianya pelayanan rawat inap dan klinik bersalin. Dalam perspektif masyarakat miskin penerima pelayanan kesehatan dari Puskesmas Sangkrah, pelayanan yang diberikan dari Puskesmas dirasakan lebih dari cukup baik menyangkut pelayanan administrasi maupun pelayana medis. Namun demikian masih ada beberapa catatan tentang harapan masyarakat terkait dengan kualitas pelayanan kesehatan terutama keterbukaan informasi yang lebih gampang dipahami oleh kelompok masyarakat miskin.

\section{DAFTAR PUSTAKA}

1. Ahmad Miftah, dkk (2009), Belajar dari 10 Propinsi di Indonesia: Upaya Pencapaian MDG's Melalui Inisiatif Multi Pihak, Kemitraan partnership, Jakarta.

2. Islamy, M. Irfan, 2007. Prinsip-prinsip Perumusan Kebijakan Negara. Edisi 2. Jakarta: Bumi Aksara.

3. Nasution, Zulkarnaen, (2002), Komunikasi Pembangunan Pengenalan teori dan penerapannya, Rajagrafindo Persada, Jakarta.

4. Robbins Stephen P.(1996), Perilaku Organisasi; Konsep Kontropersi danAplikasi (Terjemahan). Jilid

I. Prehalindo, Jakarta.

5. Sedarmayanti.(2007). Manajemen Sumber Daya Manusia. Reformasi Birokrasi dan Manajemen Pegawai Negeri Sipil, Aditama, Bandung

6. Sherraden, Michael (2006), Aset Untuk Orang Miskin, Perspektif baru usaha pengentasan Kemiskinan, Rajagrafindo Persada, Jakarta.

7. Sutopo H.B, (2006), Metodologi Penelitian Kualitatif : Dasar Teori dan Terapannya dalam Penelitian, Sebelas Maret University Press, Surakarta, 
8. Miles, Matthew B. dan A. Michael Huberman, (1992) Qualitative Data Analysis, Rohidi, Tjetjep Rohendi, UI-Press, Jakarta.

9. Parasuraman, A., Valarie A. Zeithaml, and Leonard L. Berry.(1985). A Conceptual Model of Service Quality and Its Implications for Future Research, Journal of Marketing. Vol 49 (4) pp 41-50.

10. USAID, (2008) Seri Manajemen Pelayanan Publik: Aplikasi Skema Tindaka Peningkatan (STPP) Promosi Kesehatan di Kabupaten Boyolali, Panduan Fasilitasi, LGSP, Jakarta, http://www.Igsp.or.id

11. Padang ekspres, Digital edition, Miskin-Kaya Diberi Kartu Sehat dan Pintar, Kunjungan Kerja DPRD Dharmasraya ke Pulau Jawa .http://padangekspres.co.id/?news=berita\&id=45332, 11 april 2014 pukul 13.58.

Suara suci, Inovasi Jokowi di bidang kesehatan dengan

PKMS, http://suciohsuci.blogspot.com/2012/09/inovasi-jokowi-di-bidang-kesehatan.html diakses 11 april 2014 pukul 14.19 wib. 